\title{
Nominative Determinism or Aptronyms
}

\author{
J.M.S. Pearce \\ Emeritus Consultant Neurologist, Department of Neurology, Hull Royal Infirmary, Hull, UK
}

These terms are not really of neurological origin, but as I scribble this at the New Year, this rather British diversion may serve to amuse.

In essence, these terms describe a profession or work reflected by the person's surname. No less an authority than C. Jung wondered: "Are these whimsicalities of chance, or ... are they "meaningful coincidences"?'

In October 1994, Jen Hunt wrote an article in The Psychologist called 'The Psychology of Reference Hunting'. It was remarked that J.W. Splatt and D. Weedon wrote a paper on incontinence in the British Journal of Urology! The New Scientist magazine was swamped with examples of people whose names matched their jobs. Entertaining examples abound.

A former surgical colleague was named Mr. Kille, but maintained a good practice. As did another former colleague, a venereologist Dr. Horne.

The New Scientist reported: 'S.M. Breedlove who wrote on sexual dimorphism for the Journal of Neuroscience ...'
Barry Mason is a famed British stone sculptor. Brian Mole is Head of Security, University of Sheffield. The weather presenter for the BBC's East Midlands Today news broadcast is Sara Blizzard. The World Bank country director for China is David Dollar. Gene Shearer is a Biologist with the U.S. National Institute of Health at Trinity College Dublin. Iain Atack, is a lecturer in international peace studies.

Franklin P. Adams, a famous newspaper columnist, called them 'aptronyms'. James Taranto, a columnist for the Wall Street Journal calls the phenomenon 'eponymy'. Tom Stoppard (in his play, Jumpers) calls it 'cognomen syndrome'. In its 'Frontiers' column, the British magazine New Scientist called it 'nominative determinism'. And, Gene Weingarten of the Washington Post calls them 'aptonyms'.

\section{Postscript to All Readers}

Please don't all of you send me examples!

\section{KARGER}

Fax +4161306 1234 E-Mail karger@karger.ch www.karger.com www.karger.com/ene
J.M.S. Pearce

304 Beverly Road

Anlaby, East Yorks HU10 7BG (UK) 